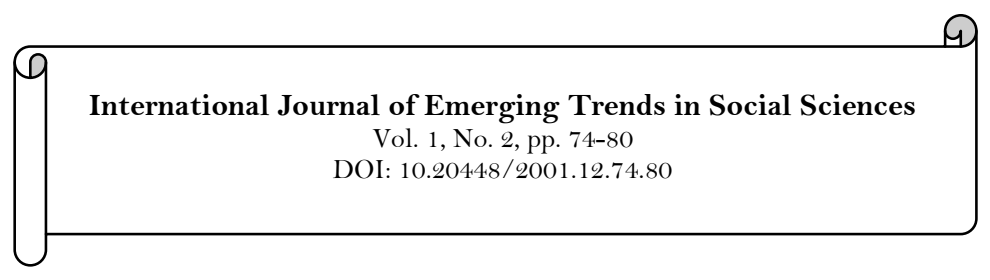

\title{
Freedom of Information Act 2011 and Press Freedom: Challenges and Prospects for Media Practice in Nigeria
}

\author{
Nsikan Senam ${ }^{1}$ \\ Uwem Udo Akpan² \\ Mbuk Mbohos \\ ${ }^{1,2,3}$ Department of Communication Arts University of Uyo, Nigeria.
}

\begin{tabular}{|c|c|}
\hline Abstract & \\
\hline $\begin{array}{l}\text { Information flow is not just a fundamental ingredient of democracy } \\
\text { but also a sine qua none to the overall development of the society. } \\
\text { Journalism plays an important role in ensuring that relevant } \\
\text { information of significance is gathered, processed and transmitted to } \\
\text { the citizenry. This paper hinged on access to and transmission of } \\
\text { information. Specifically, it examined the Freedom of Information } \\
\text { Act, } 2011 \text { and press freedom vis-a-vis their implications for } \\
\text { journalism practice in Nigeria. The paper is a product of descriptive } \\
\text { research and document analysis. Findings revealed that Nigeria's } \\
\text { Freedom of Information Act was not enacted exclusively to aid } \\
\text { journalism practice, rather for use by the generality of Nigerians. } \\
\text { However, if the applicable aspect of Act is properly harnessed by } \\
\text { journalists, the contents of Nigerian mass media would be enriched. } \\
\text { It is therefore recommended that the Nigerian Press Council should } \\
\text { sponsor a bill in the National Assembly for the enactment of } \\
\text { Journalism Practice Act in order to enhance professionalism and } \\
\text { efficiency in journalism practice. Again, Nigerian journalists should } \\
\text { not over-rely on the assurances of the Act as they are nothing far } \\
\text { from façade, rather journalists should keep engaging in investigative } \\
\text { journalism so as to publish the real truth not what public officers call } \\
\text { the truth. }\end{array}$ & $\begin{array}{l}\text { Keywords: } \\
\text { Governance } \\
\text { Law } \\
\text { Professionalism } \\
\text { Public interest and state } \\
\text { Policy. } \\
\text { Licensed: } \\
\text { This work is licensed under a } \\
\text { Creative Commons Attribution } \\
\text { 4.0 License. }\end{array}$ \\
\hline
\end{tabular}

\section{Introduction}

It is always the desire of every human being to know what is happening around him or her, or at least have a fair idea of it. This is more particularly so, when the event is of significance to the person. Appropriate and timely information helps human beings to arrive at a rational discernment. The importance of information, the humans' desire to know, and information dissemination, all constitute a remarkable chunk of what necessitated the entrenchment of the right to freedom of expression and the free press in most national constitutions. Furthermore, information dissemination is so important that it constitutes part of the fundamental human rights, - the rights that are universally recognised as belonging to all individuals by the mere fact of their humanity. Freedom of expression has been a recurrent provision in the Nigerian Constitutions since independence. For instance, Section 25(1) of the 1963 Constitution of the Federal Republic of Nigeria provided that, "Every person shall be entitled to freedom of expression, including freedom to hold opinions and to receive and impart ideas and information without interference".

This provision is similar to that of Section 36(1) of the 1979 Constitution. Similarly, Section 39 of the 1999 Constitution, as amended, 2011 provides for the Right to Freedom of Expression and the Free Press thus:

1. Every person shall be entitled to freedom of expression, including freedom to hold opinions and to receive and impart ideas and information without interference.

2. Without prejudice to the generality of subsection (1) of this section, every person shall be entitled to own, establish and operate any medium for the dissemination of information, ideas and opinions. 
The above provisions are similar in intent and purpose irrespective of the particular constitution that made them. One obvious fact is that the provisions are not made specifically for journalists. In other words there is no provision of the Nigerian constitution that specifically empowers journalists to gather and disseminate information to the exclusion of other citizens (non-journalists). The failure of the press to win a special place in the constitution has always been identified as the fear by the politicians that the press, if given more freedom, would use it against them (the politicians), considering the way the press fought the colonial administration (Udoakah, 2014). The importance of the press in governance was underscored by Thomas Jefferson, a former President of the United States of America who once said that if he had to choose between a government without a free press or a free press without a government, he would choose the latter. Thomas Jefferson made this statement before he became the President. It should be noted that during his tenure as President of the United States, Thotmas Jefferson was quoted as saying that: He who never read the day's newspapers was better informed than he who read! The foregoing summarises the pressures and conflicts between the government and the press despite the importance of the press in governance.

Information dissemination and effective communication constitute the very basis of democratic governance in any society (Senam \& Udo, 2015). Out of about six five years of Nigeria's existence as a sovereign nation, the country has experienced only about twenty six years of civil rule against twenty nine years of military rule. This has been one of the hindrances to information gathering and dissemination; the era of military rule was always anti press. The underlying fact is that military rule does not observe the tenets of democracy to which the press is a catalyst. Despite the importance of information gathering and dissemination, people's access to information of significance is, and has always been low. The situation became worsened by over reliance on the concept of "official secrets" by public officers and institutions. The above scenario poses a serious challenge to mass media practice in particular and freedom of expression generally.

Because of such challenge, various approaches have been adopted by media practitioners to overcome the melancholy. Sometimes such approaches resulted in unethical practices by some journalists; such unethical practice is "cheque book journalism" - a practice of commodification of information in which the journalist pays money to the news source or informant to get information for publication. To avert this ugly situation, other journalists resorted to fight for press freedom but the question remains, how much fruit has the fight yielded? Again, with the fight, is there realty press freedom? Or, with the freedom of information Act, is there press freedom? If there is, is it satisfactory? In other words, what are implication of the Freedom of Information Act for journalism practice in Nigeria? These issues constitute the thesis, the drive, the thrust and the motive of this paper.

\section{Press Freedom}

The press is usually referred to as the fourth estate of the realm - what a prominent position in the hierarchy for the press after the three organs of government! This ranking represents the fundamental role of the press in the society. The press epitomises the mass media; it plays a vital role in information gathering and dissemination as well as nation building. For Malemi (2009) "the press is an opinion moulder and a setter of agenda. It is an examiner of the actions of government and society, and it expresses opinions through news and editorials with a view to promoting change". With this pointer of what the press is, what it stands for and what it does, press freedom becomes not only a desire but an imperative in the life of any society.

Press freedom is "the liberty of the press to gather? process, package arid disseminate information or opinion without undue interference, hindrance or legal restriction (Senam, 2014). For Onagoruwa (1985) "Press freedom is the right of the press to publish without being subjected to intimidation, threat, molestation or blackmail". These two definitions are the operational definitions of press freedom as adopted in this paper. The development of the press and the attendant press freedom are relative issues in the various domains of the world press. Freedom of the press is of dual faces:

(i) The freedom to offer a wide range of voices.

(ii) Responding to a wide range of demands and needs of the people.

It is sad to observe that, in view of Nigeria's socio-political realities, the road to press freedom in Nigeria has always remained a bumpy one. Journalists in the country are always in a serious struggle in a bid to ensure ideal freedom of the press, both in the era of military rule and civilian administration (Senam, 2010). In view of this, it is not out of place to aver that partly because of the desire and struggle for press freedom, when General Ibrahim Badamasi Babangida (IBB) took over power in 1985, he gave the impression that his regime was going to be media friendly allowing press freedom to reign. As a step towards the materialisation of the promise of press freedom despite his atrocities, the promulgation of obnoxious decrees against the media, Babangida promulgated Decree No. 85 of 1993- The Nigerian Press Council Decree. This decree set up the Nigerian Press Council to promote professional standards for the Nigerian Press. As this aim was not realised, it seems the Press Council Decree was promulgated to temporarily divert the attention of critics from Decree No. 43 of 1993 - the Newspaper Registration Decree and Decree No. 48 - the Newspaper Prohibition and Prevention from Circulation Decree. It was expected that the Press Council would restore sanity in government- press relations, unfortunately it did not. 
According to the Nigerian Press Council Decree No. 85 of 1993, the functions of the Press Council included, to:

(i) Enquire into complaint about the press and the conduct of any person or organisation towards to the press.

(ii) Research into contemporary press development and engage in updating press documentation.

(iii) Review development likely to restrict the flow of information and raise some measures aimed at remedying such development.

(iv) Ensure the protection of the rights and privileges of journalists in the lawful performance of their professional duties.

(v) Foster the achievement and maintenance of high professional standard by the Nigerian press.

Despite the above lofty goals, the press council is still unable to ensure press freedom or even a commendable standard of journalism. Three factors are outstandingly accountable for Press Councils' failure to attain its objectives: first, the composition (comprising professionals and non professionals as well as government's stooges); second, funding (the organisation is mainly funded by government, thus subject to control by government); third, the lack of judicial power (press council adjudicates and passes sanctions that are only morality-based).

The Press Council which died a quiet death some years back is currently launching an aggressive rejuvenation. Its existence and activities are mainly heard on radio for example; "If a news report about you is inaccurate or malicious, you many seek a redress from the press council. The Nigeria Press Council is located at ... Nigerian Press Council; Your night to truthful and fair journalism!". From the fore-going, it is obvious that in Nigeria, press freedom is illusive and would remain so for a long time until the fight for it is victorious.

\section{Government and the Mass Media}

Government and the mass media are important institutions in the society that are mutually indispensable to each other. In the first place, government enacts the law through an appropriate law-making body and the law regulates all sorts of human conduct and mass media practice so as to safeguard the liberty of individuals. On the other hand, the mass media serve as agents of mass mobilisation of citizens for a smooth and cohesive society. Government must therefore work together in the overall interest of citizens and for the progress of the state. In other words, government makes the laws and policies that regulate the operation of the mass media. Such laws and policies could be through Acts of parliament, official gazette and executive declarations. Meanwhile, "government has continued to use government-owned media for the propagation of its interest. There also arises the need to strike a balance between the need to protect the interest of the government and that of the common man" (Eweleukwua, 2004).

The Government-press relationship is always a "marriage of convenience". Evidently, the parties to this relationship are not at par. Government relates with the press at the convenience of government and obstructs the activities of the press, especially in a bid to create the link between the government and the governed. The greatest means of this obstacle is through official secrecy, obnoxious law or policy, as well as of witch hunting. Thus the relationship is characterised by suspicion and antagonism. The vector of orders is usually from the government to the press. One thing is very clear, government does not like to be criticised by the press no matter the good intent of the press. As rightly put by Bill Moyers - one of several press secretaries of Lyndon Johnson, former President of the United States of America, what the press and government should seek from each other is a mutual no-poaching agreement, for the press and the government are not allies. They are adversaries to each other. How each performs is crucial to the workings of a system that is both free and open but fallible and fragile. It is the nature of a democracy to thrive upon conflict between press and government without undue assumptions.

However, no matter the nature of the government-media relationship, media practitioners must strive to do their work well and be guided by the appropriate law and professional ethics. Even so, former Governor of Cross River State of Nigeria Mr. Clemetn Ebri had stated at a public discourse on governance and the media that, embracing democracy imposes obligations on both the media and the political leadership to come to terms with the practical problems of governance. For political leaders, the challenge is one of good governance predicated on the rule of law, integrity of judiciary, respect for human rights, and the pursuit of responsible governance founded on accountability, transparency and due process. Journalists the world over, agree on these but are often impatient with the way in which politicians sometimes define and relate to these imperatives. In this regard, Mr. Ebri argued that it would run counter to the Spirit of democracy for Nigerian media practitioners to expect to be granted immunity from the laws that govern the rest of society. Similarly, Nigeria's democratically elected leaders cannot hide under the umbrella of "emerging democracies" and "a learning process" to indulge in the violation of the rights of their people or ride roughshod over the tenets of good governance and administrative best practices. 
Senam (2017) asserts that, in any kind of government media relationship or mass media ownership pattern, three categories of pressmen (journalists) are usually noticed:

(i) Journalists who are bold and objective - they usually report or like to report the truth.

(ii) Journalists who are sycophants - they use their privilege as journalists to seek favour by praising the government or its agents.

(iii) Journalists who are controversial and over-zealous - their practice is sometimes characterised by morbid curiosity, they get into trouble from time to time, in many cases, through their publications; they commit media offences such as sedition, defamation, etc and risk prosecution and conviction.

\section{Anatomy of the Freedom of Information Act (FOl Act), 2011}

The FOl Act, 2011 is one of the Laws of the Federation of Nigeria, LFN. The Bill that gave birth to the Act was an executive bill that emanated from the Olusegun Obasanjo's Civilian Administration (1999-2007). It was passed by the Senate and the House of Representatives on 24th May, 2011 and assented to by the President, Dr. Goodluck Jonathan on 28th May, 2011.

The FOl Act, 2011 is presented in 32 sections. It is a legal empowerment for every person so entitled by the Act to access public information in the custody of public officer or public institution. In view of this, it is obligatory for a public institution to ensure that, "it records and keeps information about all its activities, operations and businesses" (section 2(1)). An applicant seeking public information under the Act needs to demonstrate any specific interest in the information being applied for. Interest is the legitimate underlying motive which gives rise to the legal right to access public information or information within public domain, within the purview of the FOI Act 2011. It is a fundamental ingredient for the exercise of the right to access information under the FOI Act.

It is the legal obligation of the officer in custody of public information to release same to the applicant upon an appropriate application being made seeking such information. According to section 4(a) of the Act, where the public institution considers that the application should be denied, that is, the applicant should be denied access to the information applied for, the institution shall give a written notice to the applicant that access to all or part of the information will not be granted stating reasons for the denial. As for reasons for the denial, section 16 provides inter alia: A public institution may deny an application for information that is subject to the following privileges.

(a) Legal practitioner - client privilege

(b) Health workers - client privilege

(c) Journalism confidentiality privilege

(d) Any other professional privileges

However, a person entitled to the right of access conferred by this Act shall have the right to institute proceedings in the court to compel any public institution to comply with the provisions of Section 2 (6) of the Act. in this Act, "court" refers to the Federal High Court or High Court of a State. This means that, it is only the High Court of a State or a Federal High Court that has original jurisdiction to entertain matters relating to the application of this Act (see the interpretation section of the Act). It is instructive to note that, section 31 of the Act, "Public institution" means any legislative, executive, judicial, administrative or advisory body of the government, including boards, bureau, committees or commissions of the state, and any subsidiary body of those bodies including but not limited to committees and subcommittees which are supported in whole or in part by public fund or which expend public fund, and private bodies providing public functions or utilising public funds.

Thus, Public institution means more than an organisation owned by the government, but includes organised private sector that discharges functions or utilize public funds. With the fore-going, an examination of the implications of the FOI Act, 2011 for mass media practice now follows.

\section{The FOI Act, 2011 and Challenges of Media Practice in Nigeria}

One clear fact about the FOl Act, 2011 cum journalism practice in Nigeria is that the Act, right from its stage as a bill, received much media hype. In fact, so much was expected of the bill when it would finally metamorphose into an Act. Thus, because of the much expectation from the Act in the media circle, when it finally came on board on 28th May, 2011, many media practitioners felt disappointed that the Act did not satisfy their curiosity and expectations. This disappointment forms the central theme of the challenges of the FOl Act, 2011 vis-à-vis mass media practice, both at the state and at national levels.

The first major challenge of the Act on journalism practice is that its provisions are made for "everybody"; no provision is made for "the press" or specifically for "the media". This same scenario manifests in the 1999 Constitution. For example, section 39(1) of the 1999 constitution of the Federal Republic of Nigeria, as amended 2011, provides for the right of every person to exercise the freedom of expression including freedom to hold opinion and impart ideas and information without interference. Here lies one of the problems in the provision of section 39 (1) - inferring the "press" to be a part of "everybody". In contrast, the First Amendment 
to the United States Constitution States unambiguously: 'Congress shall make no law... abridging the freedom of speech, or of the press,- or the right of the people peaceably to assemble, and to petition the Government for a redress of grievances.'

Taking literary, the First Amendment has almost everything that a free press advocate might hope for, but those words have not often been taken literally. The crucial question is: which restrictions or freedom are constitutionally permissible and which ones are not? The purpose of clarification, the media practitioner should know that an attempt to overthrow government by force or incitement through the media is a substantial enough interest for the government to limit speech and press freedom through lawful means - the courts. Indeed, this is the ultimate value of any democratic society (Mhoho \& Anim, 2006).

The FOI Act, 2011 generally hinges on people's right to access public records and information. It is not an exclusive empower for journalism practice; in fact it is a façade. It was not made specifically to aid or guide journalism practice exclusively, rather, to guide every Nigerian citizen seeking information from a public officer or public institution.

One obvious thing about Nigerian statutes and constitution on mass media practice, is that they carry no provision which is exclusively made for journalists or to guide journalism practice for instance section 22 of the 1999 constitution, as amended, 2011 provides that: 'The press, radio, television and other agencies of the mass media shall at all times be free to uphold the fundamental objectives contained in this Chapter and uphold the responsibility and accountability of the Government to the people.' The underlying ingredient here is that it is imperative for the press to uphold the responsibility and accountability of the government to the people.

It must be noted that the above provision is not a freedom to the press, but a directive to the press on how the press should serve government interest. Malemi (2009) asserts that by virtue of the above provision, power, right, obligation and duty of the press are of dual fold:

(i) To uphold and help government to realise the fundamental objectives and Directive Principle of State policy as set forth in Cap 1 of the 1999 constitution.

(ii) To be a watchman and uphold the responsibility and accountability of the Government to the Nigerian people.

The implication is that the law expects the press to double both as nation builder and watchman as well as mouth-piece to the government.

Another challenge relating to media practice in the regime of the FOl Act, 2011 is the immediacy factor. Mass media practice, particularly journalism relies much on immediacy as a determinant of the event that constitutes news. So with the FOl Act, 2011, to wait and go through the process of applying for and obtaining information for publication, the news would have become stale since news is a perishable product.

The stringent legal technicalities in applying for and obtaining information is a challenge to the FOl Act, 2011 on media practice in the country. The Act provides guideline, timeline, procedure, and fees in applying for information under the Act. The technicalities involved therefore make the application more or less a duty of a lawyer than that of a journalist. In Nigeria, like many other democracies, most of the applications made for public document to be accessed are made by lawyers as part of their services to their clients. Such include application for court processes, application for public information that can be pleaded as evidence in litigation etc. This makes the question of the importance of the Act to media practice to continue remaining an issue for serious consideration in the media circle. The situation of non-utilisation of the opportunities created by the FOl Act is not only applicable to Nigerian journalists. The situation is similar in the United State of America. Thus, since the enactment of the American FOl Act, 1966, "its main users have been corporations, academics, researchers and private individuals with a special interest in particular topic, historians and other academicians far more than journalists" (Overbeck, 2004).

Hoarding of vital information is another challenge. The FOl Act, 2011 provides for reasonable refusal. Public officers or public institution can refuse an applicant access to public information so far as they can justify such refusal. Thus a problem would arise when the public officer knows that the application for access to a particular information is a step towards publication in the media; the officer may likely "edit and dress" the information in a way that protects the officer and the public institution but diminishes the basic ingredient of mass media content.

Another challenge is the possibility of journalists' over dependence on the cover of the FOI Act, thereby encouraging "Press Release Journalism" (PRJ). PRJ is a kind of journalism in which a journalist comfortably awaits the public officer to issue press release or any other kind of public announcement which the journalist adapts into news and nothing more. The journalist in this kind of practice usually takes no any step to investigate or go beyond the contents and claims of the press release or public announcement. This then becomes a professionalism issue in journalism.

Also, public officers' reliance on the coverage by some extant laws certainly advances some challenge to journalism practice in the melieu of the FOI Act. In Nigeria, it is very common for some public officers to hide under the cloak of some extant laws to frustrate the moves of journalists or other people seeking public information. Prominent among such extant laws is the Official Secret Act. Some rooms are christened Secret 
Registry'; some files are marked 'Top Secret' etc. The implication of this is that public officers are made to believe that nothing can cause any information within this region of secrecy to be divulged no matter the situation. In some occasions, top public officers are always reminded of their 'Secrecy Oaths' and are as such expected to kept public documents strictly secret. This is a mere blackmail, even if there is the rule of official secrecy, no such rule is higher than the FOI Act.

\section{The Freedom of 1nformation Act 2011: Prospects for Media Practice in Nigeria}

Although the challenges posed by the FOl Act, 2011 to media practice in Nigeria are many, there are some exceptions which constitute the prospects for media practice in the regime of the Act. First, with the Act, the chances of journalist being compelled to mention his source of information have been minimised. In the case of Tony and Senate (1983) the Supreme Court held, inter alia, that an editor of a newspaper cannot be compelled to disclose his source of information. However, the exception to this rule was articulated in Adikwu v. House of Representatives (1982) that a journalist can only be compelled to mention his source of information in "grave" circumstances. So, with the FOI Act, public information is considered as 'article in the overt market' since the Act guarantees easy access by members of the public.

Another prospect is the expansion of news sources. With access to public information, even by nonjournalists, it would add to available information. This then, would inversely increase and enrich information bank which in the ultimate, can constitute part of the mass media contents.

Furthermore, with the FOl Act, many public officers who would be appropriate resource persons in the media production would stop being media shy. This is so because, they now know that public information is not as "sacred" and "secret" as public officers hitherto fended them to be. This would aid media practice since media teams would be ready to hand-pick appropriate professionals as the resource persons for rich media contents. Again, protection for sources of public information is guaranteed with the FOI Act. There is a legal protection for public officers who lawfully and legitimately released information that is within their custody.

\section{Conclusion}

From the fore-going discourse, it is safe and appropriate to conclude as follows: The press has no special provision in the FOl Act, 2011 which directly guides journalism practice to the exclusion of others. This therefore affirms the fact that media practitioners do not have exclusive right from the right of any other citizen. That is to say, the FOI Act, 2011 was enacted for the generality of Nigerian citizens to enable them to access public information or information of public interest kept in public domain.

The implication of the Act for media practice is of secondary or remote effect. Generally, the freedom of Information Act, 2011 does not have as much direct and exclusive implications for journalism practice in Nigeria as it was hyped in the Nigerian media at its bill age.

\section{Recommendations}

Given the realities surrounding the application of the Freedom of Information Art and its implications for journalism practice in Nigeria, the following recommendations are proffered:

1. The Nigerian Press Council should sponsor a bill in the National Assembly for the enactment of Journalism Practice Act. This Act will certainly address matters of journalism practice which the Freedom of Information Act has not.

2. Journalists should not over rely on the freedom of Information Act as a cheap means of gathering information for public consumption. They should rather keep engaging in investigative approach to information gathering and dissemination.

3. Journalists should always investigate further and cross-check the information accessed through the application of freedom of Information Act since such information may have been specially packaged for future exposure to the public.

4. Journalists should not over-rely on government releases as a major source of news contents.

5. Government officials and custodian of public information should imbibe the spirit of accountability by readily releasing information sought for publishing. In other words they should not hoard information that is in the public domain.

\section{References}

Eweleukwua, B. N. (2004). Introduction to Nigerian press law. Onitsha: Maranatha Press Ltd.

Malemi, E. (2009). Mass media law (3rd ed.). Lagos: Princeton Publishing Co.

Mhoho, M., \& Anim, E. (2006). Mass laws in Nigeria. In: Fundamentals of human communication (pp. 204 - 221). Ibadan: Stirling-Horden Publisher Nigeria Ltd.

Onagoruwa, T. (1985). New direction for journalism in Nigeria. Enugu: Rhyce Publishers Ltd.

Overbeck, W. (2004). Major principles of media law. Belmont: Wadsworth Learning Inc.

Senam, N. (2010). An analysis of legal provisions on mass media access and restrictions in court reporting in Nigeria. Maiduguri Journal of Arts and Social Sciences, 8(2), $43-52$.

Senam, N. (2014). Mass media law and ethics. Uyo: Inela Ventures and Publishers Ltd.

Senam, N. (2017). Mass media law and ethics. Uyo: Inela Ventures and Publishers Ltd. 
Senam, N., \& Udo, I. P. (2015). Critical journalism and democratic governance in Nigeria. In: Research on Humanities and Social Science, USA, 5(10), 44-49.

Tony, M., \& Senate. (1983) (Vol. 4, pp. 269). Nigerian Law Report.

Udoakah, N. (2014). Government and the mass media in Nigeria (3rd ed.). Ibadan: Sterling-Horden Publishers Ltd. 